\title{
UNIVERSITYOF
}

FORWARD

THINKING

WESTMINSTER用

WestminsterResearch

http://www.westminster.ac.uk/westminsterresearch

Reaching Out - Engagement through Events and Festivals - the Cathedrals of England

Curtis, S.

This is a pre-publication version of a book chapter published in Butler, R. and Suntikul, W. (eds.) Tourism and Religion: Issues and Implications, Bristol, Channel View Publications, ISBN: 9781845416447.

The WestminsterResearch online digital archive at the University of Westminster aims to make the research output of the University available to a wider audience. Copyright and Moral Rights remain with the authors and/or copyright owners.

Whilst further distribution of specific materials from within this archive is forbidden, you may freely distribute the URL of WestminsterResearch: ((http://westminsterresearch.wmin.ac.uk/).

In case of abuse or copyright appearing without permission e-mail repository@westminster.ac.uk 


\section{Reaching Out - Engagement through Events and Festivals - the Cathedrals of England}

\section{Simon Curtis}

\section{Introduction}

All religions are characterised by a focus around a calendar of events yet the degree to which religion permeates the event and festival sector is much overlooked and frequently misunderstood. Traditionally, religious events closely follow the cycle of sacred beliefs which underpin the faiths but there has also been a strong link with the celebration of the seasons and harvests. In Christianity, Easter and Christmas have formed the backbone of the event calendar for centuries and Lent is preceded by the busy Carnival season, especially in Catholic countries. These religious festivals have become ever more elongated, commercialised and exploited by wider society. This in itself is an interesting and long standing trend but this chapter will concentrate its analytical eye on the link between the Christian church and the burgeoning event sector of the early twenty first century. It will focus on (Anglican) Cathedrals in England and investigate the extent to which these great institutions and buildings have harnessed their centuries-old skills and knowledge in the staging of events to explore new ways of reaching out to diverse audiences, whether local residents, tourists or pilgrims. It will reflect on the challenges and tensions which cathedrals must overcome to diversify their event portfolios and consider why events have become a much more significant aspect of their activity and mission. This review is underpinned by the author's professional interest in events and festivals and his own experience in managing a cathedral city destination (Rochester, in the southeast of England). This has been supported by secondary research and through a series of interviews and discussions with senior cathedral representative during the summer of 2015 . While the case studies are drawn from Anglican cathedrals, the trends and issues revealed have implications for cathedrals in Europe and beyond.

\section{The Church of England Attendance Crisis}

Before turning to cathedrals in detail, it is important to note the rather alarming fall in general churchgoing in England in recent decades. The latest statistics from the Church of England via the Archbishops' Council (2015) indicate that just under one million people $(980,000)$ attend church services every week in England. On average, attendance is declining at the rate of $1 \%$ per year and regular churchgoers now represent just $2 \%$ of the adult population. As recently as 1950, the regular attendance figure was estimated at three million people, or nearly $8 \%$ of the then total adult population of England (Archbishop's Council, 2015).

Within this background of decreasing regular church attendance, the Church of England looks after 16,200 places of worship, of which almost $80 \%$ are listed buildings (Church of England, 2015). A growing proportion of these churches are effectively closed and mothballed; others open for occasional special services only. Taking its lead from the Churches Conservation Trust, which now owns nearly 400 redundant (but sill consecrated) churches, the Church of England is actively 
exploring the idea of transforming under-used churches into "festival churches" (Church of England, 2015), essentially managed by local communities for community events and local cultural activity. Indeed, the Churches Conservation Trust have pioneered a number of innovative new uses for its buildings, ranging from a circus school to a well-being centre, to a network of "glamping" sites where tourists can essentially camp in some comfort under the roof and security of the church.

English churches are rather belatedly reacting to the dramatic and sustained falls in church attendance but face enormous challenges. By comparison, the fate of English cathedrals has been much less severe in terms of regular attendance. Their size, locations and splendour have enabled them to adapt to and exploit new social and cultural trends, not least through the staging of an ever diverse calendar of events.

\section{Cathedrals - A Prestige Collection of Tourist Attractions}

There are 42 Anglican cathedrals in England (there are also 21 Catholic cathedrals though these have not been studied in detail as part of this research exercise). Many of the 42 Anglican cathedrals are amongst the country's leading visitor attractions. The "Big 6" cathedrals (St Paul's in London, Canterbury, Durham, Salisbury, Winchester and York) were visited by almost 3.5 million people in 2013 (Ecorys, 2014) with total tourist visits to all cathedrals estimated to be 8.25 million. Total visits to the Anglican cathedrals of England, including attendance to regular services, have been estimated at 11 million (Theos and Grubb Institute, 2012). Overall visitor numbers have been gradually increasing since the mid 1990's, mostly due to the burgeoning tourist economy of many of the great cathedral cities. This has been partly driven by the increasing popularity of choral services (especially evensong) but also due to the widening portfolios of events which cathedrals have embraced.

Table 1: Visitor Numbers to English Cathedrals, 2013 (Tourist/Leisure Visits only)*

\begin{tabular}{|c|c|c|c|}
\hline Category & $\begin{array}{l}\text { Number of } \\
\text { Cathedrals }\end{array}$ & Characteristics & $\begin{array}{l}\text { Total Visits } \\
\text { in } 2013\end{array}$ \\
\hline Large international & 6 & $\begin{array}{l}\text { Large in scale; international } \\
\text { reputation and significance }\end{array}$ & $3,472,000$ \\
\hline Medium sized historic & 18 & $\begin{array}{l}\text { Medieval origins but more national } \\
\text { in scale and significance }\end{array}$ & $2,943,000$ \\
\hline Medium sized modern & 2 & Twentieth century cathedrals & 199,000 \\
\hline Urban cathedrals & 5 & $\begin{array}{l}\text { Less historic; located in highly dense } \\
\text { and large urbanised cities }\end{array}$ & 824,000 \\
\hline Parish churches & 11 & $\begin{array}{l}\text { Smaller cathedrals; converted } \\
\text { parish churches. }\end{array}$ & 812,000 \\
\hline Total & 42 & & $8,250,000$ \\
\hline
\end{tabular}

Visitor numbers do vary markedly between categories of Anglican cathedral as shown in Table 1. The cathedrals which register most significantly in terms of tourist visits are the 24 cathedrals rated as of national and international significance by Ecorys (2014). These great churches attract nearly $80 \%$ of all the tourist visits to all English cathedrals and it is these cathedrals which have most successfully integrated into their local tourist economies. 
It is not surprising that such cathedrals have embraced the visitor economy and become fully fledged tourist attractions. It could be argued that they were the earliest of tourist attractions and that ancient pilgrims were a forerunner of today's cultural tourist. These cathedrals offer magnificent architectural spectacles, combining exterior precincts of great charm and mystique and interior spaces of remarkable scale and beauty. Visitor motivations are diverse but for many, cathedrals can offer a spiritual experience which lifts them above other cultural attractions. For the cathedrals, tourism offers much needed income through visitor donations and secondary spend at on-site shops and catering venues.

However, while tourists are attracted by the magnificence of these formidable buildings, some potential visitors are either reluctant to step through the cathedral entrance or indifferent to the experience which they offer. This may be related to religious beliefs or, for others, a feeling that cathedrals are rather elitist institutions, representing strict conformity and tradition. Such attitudes may be encouraged by the fact that some cathedrals are surrounded by walls and grand gates and several (albeit a distinct minority) have chosen to charge visitors an entry fee, an uncomfortable barrier for many.

Despite their evident success in attracting visitors in recent decades, cathedrals have become aware that their audiences need to continue to grow and, most importantly, to diversify in profile. They have become more attuned to the advantages of developing and nurturing new audiences and to removing barriers of entry for those reluctant visitors. Events have provided an impetus to achieve this.

\section{Events, Space and Place}

For most tourist attractions, events are now an established feature of their strategic planning and management. Events are used to create media profile, to attract custom outside the high season, to bring under-used assets into production or to enhance the cultural offer of the attraction. They can be expensive and may involve risk, but successful events are regarded as an essential part of the tourist attraction business. The museum sector has led the way in recognising the values of their buildings and unique spaces to generate income from special events and also to be a platform for fundraising (Woodward, 2012). Cathedrals have adopted more expansive event programmes partly as a natural process of establishing their identity as competitive tourist attractions and exploiting their considerable advantages as event spaces.

Setting and spaces have a defining role to play in events; sometimes constraining them but often liberating and defining them. Most of England's great cathedrals enjoy generous spaces in the middle of atmospheric historic cities. The oldest cathedrals in particular are surrounded by precincts with gardens, greens, open spaces and cloisters. While some of the grounds require sensitive use, many of these open spaces provide wonderful event spaces in stunning settings, ideal for summer festivities and as backdrops for weddings and commercial events. The precincts tend to feature a wealth of interesting historic buildings which can be adapted for use as event and activity spaces. Where these are not available, the generous precincts of cathedrals have provided opportunities for sensitive new buildings to be added, and these have often been used as spaces to offer event, hospitality and catering facilities.

Cathedrals are amongst the largest and grandest of interior spaces which any event organiser could wish for. Naves with high vaulted ceilings, grand arches and galleries can provide breathtaking interiors for events with acoustics which are impossible to replicate in purpose built event venues. Cathedrals offer prestige combined with authenticity, and add a gravitas to an event which few 
other venues can compete with. Innovative new portable technologies have meant that the lighting and staging needs of event organisers can be more easily accommodated within cathedrals and that the need to be sensitive within the historic context of the building is now less of a challenge to event operatives and technicians.

Dowson (2015) has highlighted the multiplicity of purposes for Anglican churches and cathedrals to hold events, but it is suggested here that cathedral events can be broadly categorised into three types:

- those associated with the liturgy and the core Christian mission of the church;

- events developed for or by the community and for cultural purposes; and

- events developed with a primarily commercial objective.

Each of these is worthy of some detailed exploration.

\section{Liturgical Events}

The liturgy of a cathedral refers to the daily cycle of worship and services, a pattern which has been established for centuries. Most cathedrals will typically hold three or four services per day, consisting of communion, prayers and evensong, with extra services on a Sunday. In addition, there will be periodic choir practices and special sermons. Some of these require the closure of the cathedral to visitors, though most only necessitate restriction of access to certain areas. It is this daily performance and ritual within these great buildings that can substantially add to the spiritual experience for visitors. Music and choirs in particular are capable of enhancing the sensory reactions of visitors, temporarily lifting their thoughts above the clutter of the everyday. Such spiritual experiences are not necessarily religious and partly speak of the powerful and shifting combination of music, ritual, light and dark. The experience is akin to the concept of heterotopia (Foucault, 1986) whereby the visitor is taken into a sacred mind space which cannot be experienced in everyday life.

It is easy to underestimate how the ritualised nature of religion has influenced theatre and artistic performance over centuries, which has been well documented by cultural anthropologists such as Grainger (2009). Daily worship involves an element of music, parading, costuming and the creative use of light and sound. They are the natural business of the church, but they require an element of stagecraft. Such intrinsic experience in managing worship and staging services has proved invaluable as cathedrals have diversified into programming events which are additional to their core mission.

\section{Cultural and Community Events}

This category of events includes activities related to the role of cathedrals as iconic venues for music and cultural performance, and also reflect their missionary objectives around learning and education and a wider need to reach out to the local community.

Music has always been a central ethos of Christianity and the interiors of cathedrals are amongst the best acoustical spaces available to orchestras and musicians, whom they have inspired through the ages. Some commentators consider that cathedrals are the greatest expression of the relationship between music and architecture (Goldsmith and Major, no date). They work as sonic spaces as much for choirs as they do for jazz bands or modern electronic music. Musical concerts are the primary cultural use for cathedrals and indeed such concerts may be hosted in part for their contribution to raising commercial income through ticketing. Primarily, though, cathedrals are keen to present a 
varied music programme, not least to ensure that they are contributing to the cultural life of their cities. Cathedrals may develop their own festival of music, a well-known example being the Three Choirs Festival held annually between the three neighbouring cathedrals of Hereford, Gloucester and Worcester (Three Choirs Festival Association, no date). More commonly, cathedrals are keen to play a role as lead venue for their cities' own arts festivals. In Norwich, for example, the Cathedral regularly hosts concerts as part of the two week long Norfolk and Norwich Arts Festival in May. Canterbury Cathedral has long been the venue for headline productions for the Canterbury Festival in October, hosting prestige performances of visiting international orchestras, film screenings and theatrical productions.

In addition to their participation in city arts festivals, cathedrals have also increasingly become involved in national cultural festivals such as Heritage Open Days, a four-day festival managed by the National Trust and designed to open rarely seen heritage buildings and sites to the public. Another example is the nationally staged Big Draw Festival held to celebrate drawing as a tool for learning and expression, which has been embraced by several Anglican cathedrals.

After musical events, the second most prevalent event at cathedrals is the temporary "museum style" exhibition. These may be composed of artworks or be based around items held in the cathedral treasuries and archives. Major national occasions and historical anniversaries are increasingly marked by cathedrals as part of their collaborative cultural missions. Rochester Cathedral held a special service, exhibition and film screenings in 2012 to mark the $200^{\text {th }}$ anniversary of the birth of Charles Dickens who lived close to the city for many years; in 2015, a number of cathedrals (Salisbury, Worcester, Canterbury, Hereford, Lincoln) marked the $800^{\text {th }}$ anniversary of the Magna Carta with special exhibitions; and in 2016, to mark the $400^{\text {th }}$ anniversary of the death of Shakespeare, several cathedrals (Southwark, Lichfield, Hereford, Norwich) staged events ranging from outdoor theatre to exhibitions and talks.

There are examples of some cathedrals pushing the boundaries and taking more programming risks with cultural events. In October 2015, Manchester Cathedral hosted several nights of science fiction films for the Manchester Science Festival; York Minster invited local street artists into the cathedral in 2015 to create original spray paint works which then went on exhibition; the cloisters of Westminster Abbey* hosted a fashion show for Italian fashion company Gucci in June 2016.

The extent to which a cathedral is used for cultural use, especially exhibitions, is partly determined by its spaces but also by the availability, or lack, of alternative venues in the city (Theos and Grubb Institute, 2012). There is also a strong link to the cathedral educational programme, a means by which it seeks to provide for local schools but also to widen its audience by delivering outreach talks, workshops and projects throughout the city and Diocese (the wider district over which a cathedral has ecclesiastical authority).

Despite their reputation as hosts of substantial and high profile events, cathedrals remain more active as hosts of much smaller scale community events. These act as a powerful agent for building relationships within the cathedral community of volunteers and staff as well as the immediate city community and reflect the desire for communities to find a sense of belonging through shared values (Dowson, 2015). 


\section{Commercial Events}

Anglican cathedrals receive no regular state or public sector funding. Project funding from public conservation agencies such as English Heritage has declined in recent years. Cathedrals are expensive to maintain and conserve, not least as they comprise a range of buildings besides the great churches themselves. They also need to fund their day to day running, which includes salaries for their paid staff. The daily running costs of a cathedral is estimated at anything from $£ 12,000$ to $£ 20,000$ (Maxtone Graham, 2016). Cathedrals are constantly raising funds through the charitable work of their Friends (independent charities with a membership scheme) and volunteers, and at any one time there may be several fundraising campaigns running. Donations are of course important, but the financial challenges mean that any additional income which can be earned from commercial methods has become more significant. Raising revenue commercially can be controversial for a cathedral and this has been demonstrated by some adverse publicity related to charging an entry fee for visitors at cathedrals such as St Paul's in London, and also at Canterbury, York, Ely and Winchester. Raising revenue from commercial activities such as catering, retail and events is far less controversial, provided that all three are sited, managed and delivered in an appropriate and professional way.

All cathedrals are part of and involved in the corporate events market. Conferences, meetings and corporate dinners are the most lucrative of commercial events. Cathedrals actively market themselves as "venues for hire" to the corporate market, with success being largely an outcome of the quality of facilities on offer. While the cathedral nave can be used for gala dinners or awards ceremonies, most corporate events require more private meetings spaces and these are typically accommodated in purpose built facilities (Southwark and Canterbury provide good examples) or within converted historic buildings situated within the precincts. A number of cathedrals have instituted breakfast clubs, using their meeting rooms to build relationships with local businesses who may be persuaded to hold more lucrative dinners and events within the main cathedral at a future date.

The Christmas period is inevitably a busy one in terms of increased worship and community carol singing services, but also provides opportunities to raise commercial income through the hosting of Christmas markets and events. Winchester Cathedral's generous green has provided a spectacular site for an ice rink and Christmas market over the last decade. Such events do of course provide a community resource, and it could be argued that they exemplify a crossover in terms of cultural and commercial events but the defining objective is a commercial one.

Another example of a crossover event is Chichester Cathedral's Festival of Flowers, a biennial event over three days in June when the ancient medieval cathedral is transformed by up to 100 floral arrangements, accompanied by musical performances, sculptures and a garden fayre within the precincts. Ticket prices for the 2016 event started at $\mathrm{f} 10$ and sold out in advance. (Chichester Cathedral, 2016)

Graduation ceremonies have become important commercial events for those cathedrals located in cities with universities, which have found that cathedrals provide a suitably prestigious venue for graduates and their families on such a life-marking day. The precincts and greenspaces of cathedrals provide space for marquees as reception areas following the ceremonies. Some cathedrals host in excess of 10 days of back-to-back ceremonies in any one year. 
Insert photograph here (sent separately)

Caption: Figure 1: A graduation day at Canterbury Cathedral (Curtis, 2016)

One cathedral which has a well-earned reputation for developing commercial income through events is Liverpool Cathedral. It enjoys the largest internal area of any of England's Anglican cathedrals and so has been able to exploit this advantage to host evening dinners and awards ceremonies for up to 1,000 guests. It has also hosted special events for companies celebrating corporate success or anniversaries, such as Cunard. Liverpool Cathedral cut its teeth as an events venue during the city's year as European Capital of Culture in 2008 and has developed a bold and innovative attitude to event programming ever since, including the hosting of occasional rock concerts as part of the Sound City Festival, designed to support breakthrough music artists. It employs a Director of Enterprise who has asserted that "enterprise is integral to the mission of the Cathedral - we are providing a safe place to do risky things in Christ's service" (It's Liverpool, 2016)

\section{The Role of the Heritage Lottery Fund}

The Heritage Lottery Fund (HLF) has emerged as an influential and positive funding and guiding organisation to English (and wider UK) cathedrals in recent years. It was created in 1994 as one of the "good cause" organisations designed to distribute part of the proceeds from the national lottery scheme. It has awarded over $\mathrm{f7}$ billion in funds to heritage buildings and projects since its inception (Heritage Lottery Fund, 2012).

The HLF is aware of the challenging financial needs of places of worship and recognises their need to diversify activity and income generation initiatives. It has a number of different grant schemes; some designed for small and short term projects, others for major long term transformative projects. While conservation needs and building repairs often form part of these transformative projects, the HLF encourages cathedrals to develop projects which meet its priorities of encouraging community participation, fostering local partnership, improving accessibility and becoming more financially resilient and sustainable. A great deal of work is required from cathedral fundraisers to develop a large HLF project, with several rounds of bidding taking place. They can be between three and five years in development and require detailed business, activity and conservation planning. Crucially, the HLF encourage cathedrals to increase their staffing capacity as part of the bid and project process.

The HLF Increased its share of Lottery income after 2013 and a number of major funding projects are now in the formative stage. Canterbury Cathedral's $£ 20$ million "Journey" project is set to receive f12 million form the HLF to fund urgent fabric repairs but also to improve intellectual and physical access to the precincts via a new welcome centre and landscaped visitor trails. Lincoln Cathedral's f16 million "Connected" project has an $\mathrm{f11}$ million HLF grant earmarked for a new interpretation centre and restaurant and the creation of new outdoor event spaces (Heritage Lottery Fund, no date).

It is likely that there will be more of these transformative projects taking place at cathedrals over the next decade. For schemes of this type, the HLF see events and activities as a core element of the projects' outputs and as a mechanism for the cathedrals achieving their objectives related to community reach and increased participation. 


\section{Case Study - Salisbury Cathedral}

Salisbury Cathedral, located in the county of Wiltshire in the south of England, is considered to be one of the "Big 6" cathedrals and is noted for its tall spire and its vast precinct close, the largest in the UK. It hosts in excess of 1,500 services, concerts and other events each year and is committed to working with the local Destination Management Organisation, Visit Wiltshire, as well as more collaborative working with other major local tourist attractions such as the city museum and Stonehenge, just outside the city (Salisbury Cathedral, 2016). While it does not have an events policy, it does have a visual arts policy and the success of its arts exhibition programme over the last decade has both stimulated linked cultural events as well as inspiring a more open and proactive attitude to events activity. Events are seen as providing a means of diversifying the cathedral audience, and ultimately the regular congregation, and creating useful material for the learning and outreach programme. Staffing capacity has been increased in recent years and there are now two full time events officers, according to Salisbury Cathedral's Director of Learning and Outreach (Curtis, 2016). This has allowed the development of event skills and expertise within the permanent team.

The most established cultural event at the cathedral is its triennial hosting of the Southern Cathedrals Festival, a choral and musical festival staged annually and in rotation between Salisbury and neighbouring Winchester and Chichester cathedrals. The cathedral is also a core venue for the city's major annual festival, the Salisbury International Arts Festival. Other annual events now include a fashion week, an outdoor contemporary craft and heritage fayre and "have a go" carving and painting workshops. Occasional historical anniversaries are used as a platform for one-off major events, a good example having taken place in 2015 with the $800^{\text {th }}$ anniversary of Magna Carta, the most complete version of which belongs to Salisbury Cathedral. A special exhibition based around the iconic manuscript was held together with a series of events, including plays, re-enactments, concerts and debates. The full evet programme was supported by HLF funding and helped the cathedral to achieve record visitor numbers in 2015 (Salisbury Cathedral, 2016).

The cathedral refectory and chapter house are the main focus for commercial events and certain areas within the close are also available for private marquee hire. The cathedral nave, quire and chapel spaces can be hired by commercial organisations or private individuals, with fees and charges displayed on the cathedral's main web site. Additional charges apply for staffing support, staging, lighting and other equipment hire.

\section{Overcoming Challenges and Emergent Themes}

Some significant themes have emerged from this review of event activity at Anglican cathedrals. Cathedrals continue to embrace their roles as tourist attractions representing and often leading the identities of their cities. There remain barriers to activity, at some cathedrals more than others; nevertheless, there is enough evidence to suggest that cathedrals will be increasingly pushing the boundaries in terms of the frequency and content of non-religious and commercial events in the coming years. Tensions are sure to emerge from time to time but the tolerant attitude which the Anglican church personifies gives English cathedrals a unique ability to adapt to and indeed reflect societal and cultural change. Each of these will be considered in more detail. 
Cathedrals often define the cities in which they are located, especially those traditional and ancient English cities which were not heavily industrialised, such as Lincoln, Durham, Wells and Ely. Many of the historic cathedral cities of England are long established tourism destinations with an infrastructure to exploit such status, including heritage attractions, high quality public realm and a lively cultural events programme. Cathedrals have increasingly embraced their local tourist industries. They have recognised the commercial opportunities which tourism brings but also appreciate that the tourist audience can unlock funding to invest in their built fabric and their learning missions. Visitors want to discover the stories of the cathedrals' histories and these need to be interpreted and presented in an imaginative way. Tourism thus unlocks new revenue possibilities but also unlocks understanding and participation, aspects which the HLF has encouraged with its funding priorities. Cathedrals have also engaged in the wider strategic aspects of tourism and its impact on city image and identity. Many cathedrals are represented on the Boards of their county or city Destination Management Organisations (DMOs) and representatives of cathedrals engage with city-wide partnership marketing and regeneration initiatives. They have become much more outwardly focused and involved in partnership and collaborative work across the full spectrum of local culture, community and business.

There are still substantial barriers and restrictions to event activity, and much depends on the individual characteristics, locations and built environment of each cathedral. The main practical barrier for all cathedrals is the daily calendar of worship and liturgy. This does still leave opportunities on certain days and especially during the evenings and of course only tends to impact the main cathedral building and not the surrounding precincts and outer buildings. Some cathedrals are of course more fortunate than others in possessing generous grounds, spaces and unique heritage buildings which can form exciting indoor and outdoor event spaces.

There are of course philosophical barriers, usually where the Dean and Chapter retain a conservative attitude to extending event activity or where they are reluctant to empower their visitor and event staff. There may also be market barriers to event ambitions, where the city has a diverse supply of event venues, where a neighbouring cathedral is relatively close and acts as a competitor venue, or if the local corporate market is rather subdued and under-developed (especially in small cities such as Wells).

Despite these barriers, there is no doubt that cathedrals are becoming bolder and less risk averse in planning their event programmes. They are more willing to become engaged in city-wide festival activity and they have become convinced of the capacity of events to develop their overall reach and diversify their audiences. The community which surrounds them is a more secular one and, where faith exists, Christianity is increasingly working alongside other faiths. Provided that their core Christian mission and liturgy is protected, there is scope to find new ways of reaching out and connecting to people. The Christian world is a more secular place and Christian institutions have had to adapt to this. In addition, as Ostwalt (2012) has suggested, popular culture is becoming more sacred and individuals find spirituality in a variety of ways and cultural forms, many of which religious sites can embrace and capture. Where the boundaries have been pushed and events have been held which have raised eyebrows, there is little evidence of profanity or sustained controversy. Anglican cathedrals have a tradition for experimentation in architecture, art and music and are likely to be attracted by new forms of cultural expression in the future. Critics have referred to this future transition as a "spiritual supermarket" but they ignore the fact that post-modern consumption can be motivated as much by community and moral motives as by commerce and materialism (Redden, 2016). 


\section{Conclusions}

Ultimately, the Christian spirit is about tolerance and the bishops, deans and clergy of English cathedrals recognise that this requires opening up and reaching out in permissive and insecure times. People are seeking spirituality and meaning in their lives but this can come through a variety of experiences, often not directly related to religious services. Cathedrals are using events to engage the businessman, the graduate, the festivalgoer, the jazz music fan and even the fashionista into finding some spiritual value and to perhaps becoming the regular attender, volunteer or friend of the future. 


\section{References}

Archbishops' Council (2015) Cathedral Statistics 2014. London, Archbishops' Council.

Chichester Cathedral (2016) Festival of Flowers 2016. Available from http://www.chichestercathedral.org.uk/whats-on/festival-of-flowers-2016. (Accessed 14 July 2016)

Church of England (2015) Report of the Church Buildings Review Group. Available from www.churchofengland.org

Curtis, S. (2016) English Cathedrals; Events and Spiritual Capital. International Journal of Religious Tourism and Pilgrimage, 4(2) Article 3

Dowson, R. (2015) Religion, Community and Events: In Jepson, A. and Clarke, A. (eds) Exploring Community Festivals and Events. Abingdon, Routledge, 169-186

Ecorys (2014). The Economic and Social Impacts of England's Cathedrals. London, Association of English Cathedrals.

Foucault, M. (1986) Other Spaces: The Principles of Heterotopia, Lotus International 48/49, 9-17.

Goldsmith, M. and Major, D. (No Date) Cathedrals and Music. Available from http://www.npr.org/programs/specials/milestones/991103.motm.cathedrals. (Accessed 14 July 2016)

Grainger, R. (2009) The Drama of the Rite: Worship, Liturgy and Theatre Performance. Eastbourne, Sussex Academic Press

Heritage Lottery Fund (2012), Strategic Framework 2013-2018: A Lasting Difference for Heritage and People, London, HLF

Heritage Lottery Fund (No Date) https://www.hlf.org.uk (Accessed 14 July 2016)

Its Liverpool (2016) Live at Liverpool Anglican Cathedral. Available from http://www.itsliverpool.com/commerce/hymms-liverpool-cathedral (Accessed 20th June 2016)

Maxtone Graham, Y. (2016) The Price of a Cathedral - and How Deans Pay It. Spectator Magazine, 26 March. Available from http://www.spectator.co.uk/2016/03/the-price-of-a-cathedral-and-howdeans-pay-it (Accessed 12 July 2016)

Ostwalt, C. (2012) Secular Steeples: Popular Culture and the Religious Imagination, (2 ${ }^{\text {nd }}$ Edition), London, Bloomsbury

Redden, G. (2016) Revisiting the Spiritual Supermarket: Does the Commodification of Spirituality Necessarily Devalue It? Culture and Religion 17 (2), 231-249 
Salisbury Cathedral (2016) Strategy 2013-17 and Programme 2016-17. Available from http://www.salisburycathedral.org.uk

Theos and Grubb Institute (2012) Spiritual Capital - the Present and Future of English Cathedrals, London, Theos

Three Choirs Festival Association (No Date). Available from http://www.3choirs.org (Accessed $12^{\text {th }}$ July 2016)

Woodward, S. (2012) Funding Museum Agendas - Challenges and Opportunities, Managing Leisure, $17(1), 14-28$

\section{Author Profile}

Simon Curtis is a specialist in destination management and tourism development who brings over 25 years of experience in the UK tourism profession to his academic and consultancy work. Simon is a senior lecturer in Tourism Management and Events Management with the University of Westminster in London.

Simon began his career with the English Tourist Board specialising in product development and area regeneration initiatives. He then joined Touche Ross (later Deloittes) and produced strategies, development plans and feasibility studies for clients in the UK and international tourism and leisure sectors.

Simon then spent 15 years in senior positions in local government management in Kent and Medway in the south-east of England. At Kent County Council, he delivered tourism regeneration projects on the Kent coast and at Medway Council, he was Head of the Tourism and Heritage service which involved destination marketing, staging major events, the operation of the local museum and archive service, the tourist information centre, and managing Rochester and Upnor castles. Simon worked closely with Rochester Cathedral in supporting its developing role as a tourist attraction and event venue contributing to the overall destination product of Rochester and the wider Medway region.

Simon is passionate about the contribution of tourism and events to the economic and environmental revival of local areas and communities. 